\title{
Woman's Struggle to Fight Against Nazi as Reflected in Kristin Hannah's The Nightingale: A Feminist Approach
}

\author{
Raden Muhammad $\mathrm{Ali}^{1}$, Amelya Yunita ${ }^{2}$ \\ 1raden.ali@pbi.uad.ac.id \\ ${ }^{1}$ Universitas Ahmad Dahlan, Yogyakarta Indonesia \\ 2heyamelya2213@gmail.com \\ 2Universitas Ahmad Dahlan, Yogyakarta Indonesia
}

\begin{abstract}
This article aims to describe the main character's characterization of the novel The Nightingale by Kristin Hannah and identify the main character's struggle to fight against the Nazi. This research is categorized as library research in which the data are taken from books, journals, and other relevant data. This is also descriptive qualitative research with a feminist approach. The primary data are taken from the novel The Nightingale by Kristin Hannah. The research findings are: First, the novel's main character is Isabelle Rossignol or Juliette Gervaise, or The Nightingale. Her characterizations are (1) rebellious, (2) passionate, (3) brave, etc. Second, the struggle of the main character to fight against Nazi are: (1) joining the France resistance, (2) distributing the terrorist paper, (3) helping the allies to escape from Nazi's territory, (4) changing her name and starting guerilla across the mount, (5) fighting the Nazi and becoming a political prisoner, (6) trying to survive when the SS agent tortures her in prison.
\end{abstract}

Keywords: Woman struggle, Nazi, Feminist, The Nightingale

\section{INTRODUCTION}

Women's struggle is diverse. It can be discussed from the domestic problems such as intimidation and violence. It also can be discussed in the more specific problem such as women struggle to fight something. However, the discussion on women's struggle to fight against the enemy during the war is unusual. The war is almost unfamiliar for $21^{\text {st }}$-century women, but women who live during World War I and World War II might have other trauma (Douzou, 2019; Millington, 2018). France was one of the occupied countries in World War II. Germany occupied France from 1940 until 1945 (Smyth, 2020). The war has changed the French's life. Almost all French men become soldiers. During the war, German was controlled by the Nazi. They ruled all of France in aspects of life such as economy, politics, and religion. The Nazi also intimidated entrepreneurs and wealthy families by taking their best foods. The Nazi's armies also stayed in the French's house. People who refused to follow the order would lose their homes forever. Another Nazi's felonies deported and killed French Jewish and Communists. These are unforgettable tragic memories for all French people at that time (Rutherford, 2019). 
This condition triggered the French to build underground movements. Usually, the members of the movements were men, but some of them were women. Women who join the war are a result of feminism. Feminism made a significant change in women's lives. They can do the same as men do. There was no barrier between women and men in rights. All were equal. Desmawati (2018) and Reger (2017) found that the history of feminism can be divided into three waves. The first feminist wave was in the nineteenth and early twentieth century, emerging out of an environment of urban industrialism, liberalism, and socialist politics. The goal of this wave was to open up opportunities for women with a focus on suffrage. Women oppression and violence was the initial reason why the first wave emerged. Kristin Hannah's work entitled The Nightingale brings us back to World War II when Germany occupied France under Nazi. The main character of this novel is Isabelle Rossignol, who becomes a heroine in her way. Women who struggle to fight against Nazis either want to survive their lives or help their country fight against the enemy. This article will explain the main character's characterization and her efforts to fight against the Nazi.

\section{METHOD}

This research is categorized into library research because all data sources are taken from libraries. The writer classifies the sources into primary sources and secondary sources. The primary data is taken from Kristin Hannah's work The Nightingale, and the secondary data are taken from books, journals, and other sources. According to Nassaji (2015), a data collecting technique is a technique or method to collect research data. There are some steps that the researcher uses to collect the data. They are as follows (1) reading the novel carefully several times to understand the novel's content. The researcher catches the idea and finds Isabelle Rossignol's characterization as the main character and her struggle to fight against the Nazi, (2) gaining some information. The researcher visits the libraries to find several books related to feminist theory to support the research,(3) reading the sources and make some notes of sentences that can be used as the proven answers for the questions that are formulated, (4) exploring other related sources such as the internet and journals to get more information and then the researcher writes the result of the data observation to support the research.

The collected data are analyzed by the descriptive qualitative method and a feminist approach. A technique is started by statements or sentences or is described by explanation. According to Nassaji (2015) in his Qualitative and Descriptive Research: Data type versus data analysis journal, descriptive research aims to describe a phenomenon and its characteristics. It is used to clearly describe the study by choosing, considering, defining, 
and arranging the fixed data. After the data are collected, they are classified according to the subject to be discussed. The researcher tries to provide transparent information and describes the main character's fight against the Nazi, as seen in Kristin Hannah's The Nightingale. Then the data are analyzed and interpreted using the feminist analysis to reveals the novel.

\section{RESULTS AND DISCUSSION}

\section{Feminist Approach}

In terms of women in rights and political aspects, women have a relationship with liberal feminism (Gbaudi \& Allagbe, 2018; Herouach, 2019; Enyew \& Mihrete, 2018; Ogletree et al., 2019; Wulandari et al., 2019; Sipahutar, 2018). According to Guo (2019), feminist literary criticism refers to people separated and lost their self-awareness, especially women. They are under the control of other people or the surroundings. Sometimes, they are treated as an object position that leads them to lose their personalities. The feminist approach is a deconstruction theory toward the established values, theories, and interpretations made by men. This theory is built upon two basic premises: (1) men, women are created equal, and men have culturally subordinated (2) women, and therefore the patriarchy culture should be changed. Feminist literary criticism continues to be interrelated with the movement by a political feminist for social, legal, and cultural freedom and equality. It means that feminism can describe political, social, cultural freedom, gender equality between men and women, and legal protection. Feminism is also well known for its campaign for women's rights and interests. Feminist theory has assumed that there is some existing identity, understood through the category of women, who not only initiates feminist interest and goals within discourse but constitutes the subject for whom the political representation is pursued.

Politics and representation are controversial terms. On the one side, representation serves as the operative term within a political process that seeks to extend visibility and legitimacy to women as political subjects. However, on the other hand, a representative can be used as the normative function of a language that is said to reveal or distort what is assumed to be right about women's category.

In analyzing Kristin Hannah's The Nightingale, the researcher uses the feminist approach as rules and the norm that can be gained from the literary works as a discussion in this thesis. Feminist science is used as one of the approaches to analyzing literary work, particularly to study or learn the main character's fight against. 
According to Hornby (1995), the struggle is defined as trying very hard to do or achieve something difficult. It also means to make one's way with difficulty in the specific direction. The struggle can also be defined as overcoming a problem or preventing something undesirable from happening or continuing. According to Longman (1999), the struggle can be defined as trying to do something difficult. The struggle also means fighting someone. As long as we know, when we want to get something wrong, we have to act more. Sometimes we need to sacrifice without thinking about the risks we will face. All we do is to get what we want.

Kristin Hannah's work tells us about the girl who wants to live better, and she wants to live freely without any oppression because of the German occupation, which ruled all France citizens' aspect of life. That is why she needs to survive war-torn France. She has to struggle to get everything that she wants because she believes that freedom belongs to all people among the nations.

\section{Character and Characterization}

Character is significant to make a literary work enjoyable (Arfani, 2018). Character is the foundation of good fiction (Maslej et al., 2017), and it can also help the readers understand what happened in literary works. According to Leng (2012) in his book Understanding Literature, a character can be defined as a short story, novel, or play. Characters play an essential part in helping readers feel connected with a story because they often identify closely with characters. For example, readers who have felt victimized before may identify Cinderella and sympathize with her.

Conversely, they may have strong negative feelings towards nasty characters. The character is the essential part of a story to recognize individuals and figures. The reader can interpret the character from the dialogue and the action in a story. The readers can learn something as people by studying the character in a story. On the other hand, a character can be defined as a person or an identity in a literary work. The character in a literary work may be a human, supernatural, mythical, divine, animal, or an abstraction personification (Džemić \& Bihorac, 2017).

In their book An Introduction to Literature Criticism and Theory, Bennett and Royle (2009) stated that characters are the life of literature. They are the objects of our curiosity and fascination, affection and dislike, admiration and condemnation. This statement means that the characters have a relationship between the literary works and the readers. When the readers read a literary work, they can feel sympathy and antipathy through the literary work. Characters are imaginary persons who appear in fictional 
narratives or dramatic works. Characters are divided into two types. The first is the flat character, which remains virtually unchanged throughout the story and tends to be less an individual than a type. Flat characters are the merely undeveloped minor characters who appear in many stories and plays. The second one is a round character; on the other hand, it evolves or undergoes a change in the story's course and is more individualized and complex.

The main character is the character who has a role in each episode of a story. The main character around whom a narrative or dramatic work centers is called the protagonist or hero/heroine. According to Schwiebert (2005), the protagonist's primary opponent, if any, is the antagonist. The protagonist's conflict in a story can take many forms; it is not always with a personal opponent bent on destruction. The protagonist is the very central character or the landing actor or actress. The protagonist character is usually portrayed as a hero who has a good character such as good-looking, rich, kind, vital, etc. The readers tend to sympathize with the protagonist character because of their excellent characteristics. The antagonist is the opposite of the protagonist, and it refers to the enemy or the protagonist's challenger. The last is a companion or a partner.

The protagonist usually has a companion or a partner. They are pursuing their duty, career, struggle, or aspiration of the protagonist. They are usually a close friend or a reputable person and help the reader judge who the protagonist is. The companion or partner also plays an essential role in the story. Just the same as a companion, the minor character is the one who supports the main character or significant character. The appearance of the minor characters in a whole story is rare and not very important. The minor characters play less essential roles in a story (HE, 2020). They have a simple part of the story. Generally, the characterization aspects of literary works that can be analyzed include the characteristics, attitude, character, behavior, and related qualities of characters.

\section{The Main Character's Characterization}

The main characters of the novel are Isabelle Rossignol and Vianne Mauriac. Each is embarking on her dangerous path toward survival and freedom in German-occupied. Nevertheless, the researcher decides to analyze Isabelle Rossignol. She is the one who plays the more critical role in the whole story. The Nightingale, which is known as the title of this novel, is taken from Isabelle's name code that is why Isabelle's storyline is dominant in this novel. The Nightingale is the meaning of Isabelle's surname, which is 
Rossignol. Her storyline is more dramatic than other characters because her story is most dominant compared to the other characters.

As the author writes in this novel, Isabelle is a rebellious eighteen-year-old girl searching for purpose with all youth's reckless passion. When Parisian try to hide their fear because of the war's terrors, Isabelle decides to join the resistance and never looks back, taking a risk on everything she has to save her fellow countrymen, even her own life. She is described as the one who rebels the most with her perspective about freedom, war, and justice. She is also the most daring character. Here is some of Isabelle's characterization in the novel The Nightingale. First, she is rebellious. Rebellious means were deliberately disobeying someone in authority or fighting against the government by using violence (Longman, 2009). Isabelle's rebellious characteristic can be proven by the quotation below:

"Are you ready ?" "I am not going, Papa. I have told you this." "We will not have this conversation again, Isabelle; the Humberts will be here soon to pick you up. They will take you as far as Tours. From there, I leave it to your ingenuity to get to your sister's house. Lord knows you have always been adept at running away." "So you throw me out. Again." "Enough of this, Isabelle. Your sister's husband is at the front. She is alone with her daughter. You will do as I say. You will leave Paris." ( Hannah, 2015).

This quotation shows us Isabelle's rebellious character. She refuses her father's suggestion to leave Paris when the Nazis come and start to invade this town. She wants to stay in Paris with her father. She wants to help France soldiers; at least she may become an ambulance driver or a nurse. However, her father forbids it. The sentence "I am not going, Papa. I have told you this." shows how rebellious she is. This sentence also shows how she ignores her father's suggestion. The second main character's characterization is passionate. Passionate is the act of showing a strong feeling or belief in something (Hornby, 1995). Isabelle, in the novel, indeed owns this character. Isabelle always shows her firm belief that someday she will succeed in driving out Nazi from her country. This Isabelle's trait can be proven by the quotation below:

"A woman can go to war these days," Isabelle said when the Paris traffic finally forced her to slow down. "I could be an ambulance driver, maybe. Alternatively, I could work on breaking secret codes. Alternatively, charming the enemy into telling me a secret location or plan. Remember that game" "War is not a game, Isabelle." I believe I know that, Christophe. However, if it does come, I can help. That is all I am saying." (Hannah, 2015)

When she drives a car, she has a conversation with Christophe about the war. She believes that a war is like a game where she can play her role. She wants to be a heroine by doing tricky things such as become a spy or become a secret code breaker. Even ADJES Vol.7, No. 2, September $2020: 55-67$ 
though Christophe tells her many times about his giving up on the war, Isabelle still believes in what she had. It looks impossible to do for a woman, but she still stands to join the war and fight against the enemy. The third characterization of Isabelle is brave. Brave is defined as dealing with danger, pain, or difficult situations with courage (Longman, 2009). Isabelle is the main character of this novel, which has its character. It proves by some quotations such as: "Isabelle stared at the airman. Everyone knew the penalty for helping British airmen. It was announced on billboards all over town: imprisonment or death." (Hannah, 2015). The other proof is "Isabelle went to the airman. As she neared him, she saw the scratches on his face and the way something had torn the sleeve of his flight suit. She was pretty sure dried blood darkened his hairline, and she thought: He dropped bombs on Germany." (Hannah, 2015)

This quotation explains to us that Isabelle does not doubt the Nazi's rule. She helps the British airman who felt in Nazi's occupied zone even though there are so many announcements about punishment for everyone who helps the allied escape from the Nazi's occupied zone. She is the brave one when her friends hide in their camp, but Isabelle takes the risk to save the allied man. The second quotation proves that Isabelle's characteristics and firm belief that the airman has done the right job. He dropped bombs on German. This is the one thing that he wants to hear from Isabelle. She refuses the Nazi's rule, and she does not scare off the punishment from everyone who helps the Nazi's enemy. The fourth characterization of the main character is adventurous. Adventurous is defined as willing to take risks or try out new methods, ideas, or experiences (Hornby, 1995). This character is embedded in Isabelle's. It can be proved from the quotation below:

"I am not hiding out in the country while the Nazis destroy France. Moreover, let"s face it, you have never exactly felt sisterly toward me." Her aching face tightened." I"Il be leaving as soon as I can walk." (Hannah, 2015)

Isabelle hates to be a loser. She hates to be a passive person like Vianne did. When their house is billeted by one of the Nazi's captains, Isabelle feels like living in the wrong house. She wants to leave this house, but her sister abandons her. Isabelle wants to kill the captain if he stays in her house or leaves and fights them, but Vianne abandons both Isabelle's plans. Vianne always asks Isabelle to stay there with her and Sophie. Vianne thinks that there is no other choice. If they leave the house, they will lose everything, such as their property. Here is another quotation that proves Isabelle's adventure:

"Isabelle was elated. For the first time since the armistice, she was not completely alone in her need to do something for France. The men told her 
about dozens of groups like theirs throughout the country, mounting resistance to follow de Gaulle. The more they talked, the more excited she became at the prospect of joining them. Oh, she knew she should be afraid. ( They told her often enough.)" ( Hannah, 2015)

In the end, Isabelle leaves Vianne's house and joins the resistance. This is one of evidence of Isabelle's adventurous disposition. She can put her family, even herself, on a dangerous path, but she is still on her point. Her sister has told her how risky it French people to join the confrontation to fight against the Nazis. Isabelle joins the fighting, which Jewish and Communists manage. Nazi targets Jewish and Communists. Here is also another quotation that proves Isabelle's characterization:

"Dangerous was an understatement. There were signs posted throughout Carriveau about the execution that were taking place all over the Occupied Zone. The Nazis were killing French citizens for the smallest of infractions. Aiding this Free French movement could get her imprisoned at the very least. Still, she believed in a Free France the way her sister believed in God." (Hannah, 2015)

This quotation shows us how Isabelle risks herself to save her country. Nazi will kill everyone who breaks their rules, but Isabelle is not afraid of this. Isabelle still believes in a Free France the way her sister believes in God. It means that Isabelle's strong beliefs of something are unbreakable even she has to pass the dangerous way or the Nazi might kill even her. The fifth characterization of Isabelle is rude. In the online Oxford Dictionary, rude is defined as offensively impolite or bad-mannered. Isabelle has this character, which can be proved in some quotations from this novel. Here are the quotations that prove Isabelle's rude:

"Generally, Madame, the failing of a student to learn is the failing of the teacher to teach." Madam said," So we are the reason you still cannot manage to eat an orange properly." (Hannah, 2015)

Isabelle's rudeness makes her teacher give up on teaching her. When Madame Dufour asks why she did not do as well as the teacher teaches, Isabelle answers her rudeness. She said that the failure of a student to learn is the failure of the teacher to teach. She wants to tell her teacher that she hates the lesson of peeling oranges and table manners. However, she speaks impolitely, and her attitude is also wrong. So after that, her teacher sends Isabelle to meet the Dean. The quotation above proves that Isabelle has a rude characterization. She talks impolitely to her teacher, and she also did"t follow the teacher"s order well. Here also the quotations which prove Isabelle"s characterization: 
"Sit down, Isabelle." "Madame Dufour asked me to tell you that the experiment is over." " I hate oranges." "Pardon ?" " And if I were to eat an orange which, honestly, Madame, why would I when I do not like them I would use my hands as Americans do. Like everyone does. A fork and knife to eat an orange ?" "I mean, why are you at the school?" "Oh. That. Well, the Convent of the Sacred Heart in Avignon expelled me. For nothing, I might add." (Hannah, 2015)

The other proof of Isabelle's rude is the following passage :

"I think it"s time for you to leave." Isabelle got to her feet. "Shall I return to the orange lesson?" "You misunderstand. I mean you should leave the school, Isabelle. It is clear that you are not interested in learning what we have to teach you." "How to eat an orange and when you can spread cheese and who is more important, the second son of a duke or a daughter who won"t inherit or an ambassador to an unimportant country? Madame, do you not know what is going on in the world?" (Hannah, 2015)

In these quotations, Isabelle explains to the Dean her reason why she cannot learn well. The reason is she dislikes orange. The Dean asks her some questions about her reason for studying at that school. Isabelle answers rudely. Finally, the Dean said that Isabelle has to leave her school as soon as possible. She cannot follow the lessons well; her bad attitude and rudeness make her drop out of school.

\section{Isabelle Rossignol's Struggle to Fight Against Nazi}

The struggle that is depicted in the novel The Nightingale is done by the main character and all companion characters that stand to Isabelle in the novel. To make it specific, and because this article applies a feminist approach, the researcher would like to focus on the struggle of a woman named Isabelle Rossignol to fight against Nazi. However, it does not mean that the struggles of the minor characters are less important. Their struggle is equally important and as worthy as Isabelle's.

The main character has some struggles which would be divided into four parts. First is joining the France resistance. Isabelle's struggle is inspired by Edith Cavell. She states it many times. Edith Cavell is the famous hero in the first world-war. The struggle of Edith Cavell inspired Isabelle to fight against the enemy. But her hero is killed by German when she is captured and becomes a hostage then shot.

"Isabelle was elated. For the first time since the armistice, she wasn't completely alone in her need to do something for France. The men told her about dozens of groups like theirs throughout the country, mounting a resistance to follow de Gaulle. The more they talked, the more excited she became at the prospect of joining them. Oh, she knew she should be afraid. (They told her often enough.)" (Hannah, 2015) 
She joins the resistance and fights together with people who have the same thought as Isabelle. They have secrets activity such us spying, distributing terrorist paper, helping Jewish and communist to escape from the Nazi's territory and helping the allies to escape and destroy Nazi's territory. Isabelle's activity on the first day is distributing the terrorist paper. The head of the resistance decided to give Isabelle important duty because she is a young girl with an innocent look. So the Nazi will not be suspicious of Isabelle's activity. Isabelle always prepares her plans very well, she is also brave and smart. That is why the head of resistance gives her this job under a strong assumption that she will never be captured by Nazi.

"Isabelle drew in a sharp breath. She had been accepted! A sense of destiny seemed to fill the room. She would do something that mattered now. She knew it." (Hannah, 2015)

Second, distributing "Terrorist Paper ". Nazi propagates French by making propagate posters which can be easily found in the public places. If anyone break the posters or maybe just rip them off the wall, Nazi will shoot them. French should pass this gloomy day by following the rules or going outside and fight them. Isabelle works as a distributor of terrorist paper which is printed by the France resistance. Of course, this job is risky. She can be shot at any time when Nazi knows her activity. Distributing terrorist paper is one of her struggle to fight against Nazi. This job is given by France resistance. This quotation bellow proves that Isabelle becomes the terrorist paper distributor:

"The winter of 1940 was the coldest anyone could remember. Snow fell day after day, blanketing the trees and fields; icicles glittered on drooping tree branches. And still, Isabelle woke every Friday morning, hours before dawn, and distributed her " terrorist papers," as the Nazis now called them." (Hannah, 2015)

Truthfully, the goal of distributing terrorist papers is to help French people realize that the war is real. Some of them are careless and hopeless when Nazis take everything they have. They just follow the water stream, they have neither struggle nor power to fight Nazi. Third is helping the allies to escape from Nazi's territory. When the second world-war begins, France was occupied by Nazi Germany in all aspects of life. Freedom is only in people's dreams. There are many superpower countries who join the second world war. Some of them fight Nazi. The Nazi's enemy called as the ally for Nazi's occupied countries such as France, Sweden, and Poland. One of the allies is British army. The British army starts their guerilla by bombing Nazi's occupied zone in France. They are bombing Nazi by airplanes. When Nazi realized that they are in danger, they prepare 
their army to shot British airmen from the land. Many British airmen shot and fell down to the ground. Some of them are killed, some of them dying and some of them hiding in the forest, waiting for the miracle. If they can escape the territory they will be save, but when they are found by Nazi, of course, they will be killed.

Isabelle and her resistance know this moment. They thought that helping the allies escape from Nazi territory is the right choice in order to give assistance. She goes to the forest and looks for British airmen who fall down. She helps and brings them to a safe place. As the quotations as follows :

"Not all of us are passive," she said to the young man.

"Thanks, God. My aeroplane crashed four days ago. I've been crouching in dark corners ever since. I didn't know where to go till this man grabbed me and dragged me here. You will help me?"

She nodded.

"How? Can you get me back home?"

"I don't have the answers. Just do as they tell you, and Monsieur?" (Hannah, 2015)

"Yes, ma'am?"

"They are risking their lives to help you. You understand that?" He nodded. (Hannah, 2015)

The British airplanes were crushed four days ago when they dropped bombs in Nazi territory. Now the Nazi's army is doing guerilla to look for British airmen who fall down. Some of them died when their airplanes crashed, some of them are safe and they run into the woods. Here is the quotation which shows how Isabelle saves the British airmen from the Nazi territory.

"Isabelle swallowed hard. She had thought-briefly-of imprisonment and execution. This was something she had never ever considered. Of course, she should have.

"What we all demand of each other-or, hope for, at any rate, is two days?"

"Two days? Isabelle said. "That's not so long." (Hannah, 2015)

The fourth struggle is trying to survive when the SS Agent tortures her in the prison. It's been two days since Isabelle was captured by SS agents and hostaged in a prison. In the prison, she gets tortured when an SS agent interrogates her about The Nightingale. All she feels is pain as quoted below:

"Everything hurt. Her head, her face, her body. It took effort and courage to lift her head. She was still bound at the ankles and wrists. The ropes chafed against her torn, bloodied skin, cut into her bruised flesh. Where am I?' (Hannah, 2015)

She felt terrible pain, her body was bleeding from head to toe. What you pay is what you get, this is what Isabelle should get after all her struggle to fight against Nazi. 
She has to realize that the pain is real. Isabelle tries to remember where she is. Is it in

the same place or moved to the other room?

\section{CONCLUSION}

After analyzing the novel through a feminist approach and based on research findings, the researcher concludes. The main character is Isabelle Rossignol, who has a big ambition to fight against the Nazi. She is a rebellious, passionate, brave, adventurous, and rude woman. In struggling to fight against the Nazi, she did some actions such as: joining the France Resistance, distributing "Terrorist Paper," helping the allies to escape from Nazi's territory, changing her name and starting guerilla across the mount, becoming a political prisoner, and surviving when the SS agent tortures her in prison.

\section{REFERENCES}

Arfani, S. (2018). The Schizophrenia in The Main Character of A Beautiful Mind movie Directed by Ron Howard. Wanastra: Jurnal Bahasa dan Sastra, 10(1), 9-16.

Desmawati, E. (2018). Analysis of feminism in the novel little women by Louisa May Alcott. Journal of Language and Literature, 6(2), 91-96.

Douzou, L. (2019). A Perilous History: A Historiographical Essay on the French Resistance. Contemporary European History, 28 (1), 96-106. doi:10.1017/S0960777318000619

Džemić, K., \& Bihorac, A. (2017). LITERARY FIGURE AS MAIN STRUCTURAL ELEMENT IN LITERARY WORK. Knowledge International Journal, 174), 1607-1611.

Enyew, B. E., \& Mihrete, A. G. (2018). Liberal feminism: Assessing its compatibility and applicability in Ethiopia context. International journal of sociology and anthropology, 10(6), 59-64.

Gbaguidi, C., \& Allagbe, A. M. (2018). African Social Appraisals of Women's Liberal and Radical Feminism in Selected Contemporary West and Central African Female and Male Novels. International Journal of Linguistics, Literature and Culture, 4(6), 42-52.

Guo, Rongqiong. (2019). Brief Analysis of Feminist Literary Criticism. Proceedings of the 2018 International Workshop on Education Reform and Social Sciences (ERSS 2018). https://doi.org/10.2991/erss-18.2019.91

Hannah, Kristin. (2015). The Nightingale. US.St. Martin Press.

$\mathrm{HE}$, Y. (2020). Rethinking Minor Literature and Small Literature as Secondary Zone Literature. Territories: A Trans-Cultural Journal of Regional Studies, 2(1).

Herouach, S. (2019). Liberal Feminism Impact on Moroccan Educated Women: Faculty of Letters and Human Sciences, FLDM, as a Field Study. Open Political Science, 2(1), 128-152.

Maslej, M. M., Oatley, K., \& Mar, R. A. (2017). Creating fictional characters: The role of experience, personality, and social processes. Psychology of Aesthetics, Creativity, and the Arts, 11(4), 487.

Millington, C. (2018). Getting Away with Murder: Political Violence on Trial in Interwar France. European History Quarterly, 48(2), 256-282. https://doi.org/10.1177/0265691418754474

Nassaji H. (2015) Qualitative and descriptive research: Data type versus data analysis. Language Teaching Research, 19(2):129-132. doi:10.1177/1362168815572747 
Ogletree, S. M., Diaz, P., \& Padilla, V. (2019). What is feminism? College students' definitions and correlates. Current Psychology, 38(6), 1576-1589.

Reger, Jo. (2017). Finding a Place in History: The Discursive Legacy of the Wave Metaphor and Contemporary Feminism. Feminist Studies, 43 (1), 193-221. doi:10.15767/feministstudies.43.1.0193

Rutherford, Jeff. (2019). The Indoctrination of the Wehrmacht: Nazi Ideology and the War Crimes of the German Military, German History, Volume 37, Issue 4, December 2019, Pages 600602, https://doi.org/10.1093/gerhis/ghz071

Schiewbert, John. (2005). Reading and Writing from Literature. Boston: Houghton Mifflin Company.

Sipahutar, C. H. (2018). Feminism in Abidah El Khalieqy's Novel Perempuan Berkalung Sorban. KnE Social Sciences, 149-155.

Smyth, G. (2020). Denunciation in the German-Occupied Channel Islands, 1940-1945. Journal of British Studies, 59(2), 291-314.

Wulandari, M. D., Supiastutik, S., \& Pujiati, H. (2019). The Representation of Liberal Feminism in A Woman Is No Man by Etaf Rum. Lentera: Jurnal IImiah Kependidikan, 12(2), 237-248. 